\title{
Autosomal Recessive Motor and Sensory Neuropathy with Excessive Myelin Outfolding in Two Siblings
}

\author{
F. Barbieri, R. Santangelo, G. Capparelli, A. Ciccarelli and C. Crisci
}

\begin{abstract}
Two siblings, a 35-year-old male and a 37-year-old female, offspring of first cousins, presented with a hereditary motor and sensory neuropathy with type I clinical features which began to manifest at about age 10 years. Nerve biopsy in the proband showed it to be a type characterized by excessive myelin outfolding. Morphometric study revealed hypomyelination with focal thickenings due to outfoldings. Clinical, electrophysiological and morphological findings are virtually identical to those described by Ohnishi et al. The peculiarity of the neuropathological picture suggests a particular form of hereditary motor and senory neuropathy.
\end{abstract}

\begin{abstract}
Résumé: Neuropathie sensitivo-motrice autosomale récessive avec plissements excessifs de la myéline chez deux membres d'une même fratrie. Un homme âgé de 35 ans et sa soeur âgée de 37 ans, issus d'une union entre cousins germains, ont consulté pour une neuropathie hèréditaire motrice et sensitive, avec des manifestations cliniques du type l, ayant débutée vers l'âge de 10 ans. Une biopsie nerveuse effectuée chez le cas index a montré des plissements excessifs de la myéline. L'étude morphométrique a révélé une hypomyélinisation avec des épaississements en foyers dus aux plissements de la myéline. Les observations cliniques, électrophysiologiques et morphologiques sont virtuellement indentiques à celles décrites par Ohnishi et al. Ce tableau neuropathologique est particulier et suggère qu'il s'agit d'une forme distincte de neuropathie hèréditaire motrice et sensitive.
\end{abstract}

Can. J. Neurol. Sci. 1994; 21: 29-33

Hereditary motor and sensory neuropathies (HMSN) are a group of heterogeneous disorders classifiable into various types according to clinical, genetic, electrophysiological and neuropathological characteristics. Of these forms, HMSN type I and III (heterogeneous groupings themselves) are hypertrophic neuropathies. In type III (Dejerine-Sottas disease; congenital hypomyelination polyneuropathy') inheritance is autosomal recessive, while in type I (hypertrophic Charcot-Marie-Tooth disease) it can be autosomal dominant (HMSN types IA and IB) or, rarely, autosomal recessive, $\mathrm{X}$-linked dominant or recessive. ${ }^{2}$ Molecular genetics showed DNA duplication in $17 \mathrm{p} 11.2$ in HMSN type $I A,{ }^{3,4}$ while linkage studies allowed gene locus mapping in HMSN type $\mathrm{IB}^{5,6}$ and in X-linked dominant form. ${ }^{7,8}$

Recently attention has been drawn to sporadic/autosomal recessive cases of congenital demyelinating motor and sensory neuropathy characterized by phenomena of focal myelin thickenings. ${ }^{9-13}$

In 1989 Ohnishi et al. ${ }^{14}$ described in two Japanese patients a hypertrophic motor and sensory neuropathy with autosomal recessive transmission, and excessive myelin outfolding. To our knowledge very few other cases of this disorder have been described in the literature since then. ${ }^{15}$

We present a clinical and electrophysiological study on two siblings, and sural nerve biopsy of the proband only, whose parents were first cousins, and who present characteristics analogous to the cases described by Ohnishi et al. ${ }^{14}$

\section{Case Reports}

\section{Patient I}

S.S., a 35-year-old male, proband, third of ten children, presented with gait difficulty by about age 10 years, followed by marked atrophy and weakness of the hand and forearm muscles. At age 15 he underwent several surgical operations to correct pes cavus and at age 28 he had surgery to correct a right inguinal hernia.

On admission to our department, steppage gait, marked atrophy and weakness of the hand and forearm muscles, atrophy of the leg anterolateral muscles, and pes cavus were present. He was unable to stand or walk on the heels. Tendon reflexes were absent. Vibration sense was distally markedly reduced at the lower limbs and slightly at the upper limbs. Touch and pain sensations were slightly decreased below the middle portion of the leg. Romberg sign was negative. On palpation the nerves were not thickened.

Needle electromyography revealed signs of severe neurogenic muscle damage. Electrophysiological tests (Table 1) showed markedly reduced nerve conduction velocity, indicative of a predominantly demyelinating pathology. A sural nerve biopsy was performed.

Neurological examination of the proband's three offspring ( 2 male, 1 female) gave normal results. No electrophysiological tests were performed.

From the Department of Neurology, School of Medicine, Federico II University Naples, Clinica del Lavoro Foundation. Medical Center of Campoli. Campoli. (C.C.) Italy.

RECEIVED APRIL, 6, 1993. ACCEPTED IN FINAL FORM SEPTEMBER 23, 1993.

Reprint requests to: Prof. F. Barbieri, Clinica Neurologica, II Facoltà di Medicina e Chirurgia, Via S. Pansini 5, 80131 Napoli, Italy. 
Table 1. Electrophysiological findings. In brackets are reported the lower normal values ${ }^{18}$ used in our laboratory.

\begin{tabular}{|c|c|c|c|c|c|c|c|c|}
\hline & \multicolumn{4}{|c|}{ MCV in median nerve } & \multicolumn{4}{|c|}{ SCV in median nerve } \\
\hline & \multicolumn{2}{|c|}{ Amplitude $(\boldsymbol{\mu V})$} & \multirow{2}{*}{$\begin{array}{l}\text { Distal latency } \\
\text { (msec) }\end{array}$} & \multirow{2}{*}{$\begin{array}{l}\operatorname{MCV}(\mathrm{m} / \mathrm{sec}) \\
\text { Elbow-Wrist }\end{array}$} & \multicolumn{2}{|c|}{ Amplitude $(\boldsymbol{\mu V})$} & \multirow{2}{*}{$\begin{array}{l}\text { SCV }(\mathrm{m} / \mathrm{sec}) \\
\text { III Dig.-Wrist }\end{array}$} & \multirow[b]{2}{*}{ Wrist-Elbow } \\
\hline & Wrist & Elbow & & & Wrist & Elbow & & \\
\hline S. S. & $0.22(8)$ & $0.18(7)$ & $13.6(3.9)$ & $8.7(54)$ & 0 & 0 & 0 & 0 \\
\hline S. R. & $0.25(8)$ & $0.30(7)$ & $10.9(3.9)$ & $11.7(54)$ & 0 & 0 & 0 & 0 \\
\hline \multicolumn{5}{|c|}{ MCV in ulnar nerve } & \multicolumn{4}{|c|}{ SCV in ulnar nerve } \\
\hline & \multicolumn{2}{|c|}{$\underset{\text { Wrist }}{\text { Amplitude }}(\mu \mathrm{V})$} & \multicolumn{2}{|l|}{$\begin{array}{l}\text { Distal latency } \\
\text { (msec) }\end{array}$} & \multicolumn{2}{|c|}{$\begin{array}{c}\text { Amplitude }(\mu \mathrm{V}) \\
\text { Wrist }\end{array}$} & \multicolumn{2}{|c|}{$\begin{array}{l}\text { SCV }(\mathrm{m} / \mathrm{sec}) \\
\text { V Dig.-Wrist }\end{array}$} \\
\hline S.S. & \multicolumn{2}{|c|}{$3.30(8)$} & \multicolumn{2}{|l|}{$10.7(3.1)$} & \multicolumn{2}{|c|}{$0.72(5.5)$} & \multicolumn{2}{|c|}{$11.8(46)$} \\
\hline S. R. & \multicolumn{2}{|c|}{$4.00(8)$} & \multicolumn{2}{|l|}{$9.2(3.1)$} & \multicolumn{2}{|c|}{0} & \multicolumn{2}{|c|}{0} \\
\hline
\end{tabular}

$\mathrm{MCV}$ : motor conduction velocity; SCV: sensory conduction velocity; Dig. = Digitus; $0=$ no response

\section{Patient 2}

R.S., a 37-year-old female, second born, began to have gait difficulty by about age 12 years; a few years later she noted wasting and weakness of the hands, particularly the right. On admission to our department neurological examination showed: steppage gait, inability to stand or walk on the heels, pes cavus, bilateral atrophy of the leg muscles, marked amyotrophy of the distal third of the forearms and hands, claw hands and severe reduction in strength; tendon areflexia in all four limbs; distally reduced vibration sense more marked in lower limbs. Romberg sign was negative. On palpation the nerves were not thickened.

Electrophysiological tests gave results virtually identical to those of the proband (Table 1). The patient refused to undergo biopsy of the sural nerve.

The father, deceased at age 58 from intestinal cancer, was not examined by us. He did not present difficulty in gait, pes cavus or evident amyotrophy at the hands. The mother, age 62 , was found normal on neurological and electrophysiological examination. None of their remaining 8 children presented clinical signs of peripheral neuropathy.

\section{METHODS}

Orthodromic sensory (SCV) and motor conduction (MCV) velocity was studied in the two patients along the median nerve from digit 3 to elbow, in the ulnar nerve from digit 5 to wrist; MCV was also performed in the peroneal nerve, according to the technique described by Buchthal and Rosenfalck ${ }^{16}$ and by Behse and Buchthal ${ }^{17}$. The sensory responses were led off via near-nerve needle electrodes and 512-1024 sweeps were electronically averaged. Motor conduction velocity was determined analogously according to standard procedures, using surface recording electrodes and needle stimulating electrodes. Nerve conduction and sensory and motor potential amplitudes were compared to the age-matched control groups ${ }^{18}$ (Table 1). Needle electromyography was performed in the left tibialis anterior and in the right abductor digiti minimi muscles in both patients.

A biopsy of the sural nerve was performed above the lateral malleolus in the proband. The specimen was divided into two parts: one for light microscopy and morphometry, and one for electron microscopy which was further subdivided; both fragments were fixed in $2.5 \%$ glutaraldehyde in cacodylate buffer $(\mathrm{pH} 7.4)$ at $4^{\circ} \mathrm{C}$ for $2 \mathrm{~h}$, postfixed in $2 \%$ osmium tetroxide in the same buffer for $2 \mathrm{~h}$, dehydrated in a graded alcohol series, and embedded in Epon 812. One-micrometer sections of the whole nerve were cut transversally and stained with $0.1 \%$ toluidine blue for light microscopy. The same sections were used for the morphometric study. The G-ratio (axon $\varnothing /$ total fibre $\emptyset$ ) and the myelin area / axon area ratio were also calculated in 250 fibres ( $25 \%$ of all myelinated fibres) chosen by a systemic random method (every other field); images were analysed by VIDASZeiss equipment. Ultrathin sections were cut on an LKB Nova ultramicrotome, stained with uranyl acetate and lead citrate, and examined with a Philips EM 301 electron microscope. Teased fibre procedure was not performed.

\section{RESULTS}

Conduction studies in the median and ulnar nerves are shown in Table 1. In the peroneal nerve, no sensory or motor potential could be detected. Needle electromyography showed in both patients a marked increase in duration of the motor unit potentials $(+70 \%)^{18}$ and a normal incidence of polyphasic potentials.

Microscopically, the nerve consisted of 10 hypertrophic fascicles. The epineurium and perineurium were normal. The prominent features were a markedly reduced number of large myelinated nerve fibres, demyelinated and remyelinating axons, numerous onion bulb formations and particularly the presence of a high number of fibres with markedly irregular contour and thickness of the myelin sheaths (Figure 1). On longitudinal section these irregularities were found in both inter- and paranodal regions, and seemed to be linked to the presence of irregular myelin foldings (Figure 2).

Morphometrically, the total number of myelinated fibres was 1858 (normal values in our laboratory, based on eleven normal subjects: $5600-10700$ ) and their density was $1010 / \mathrm{mm}^{2}$ (n.v.: 6100-12200); the endoneurial area was enlarged: $1.84 \mathrm{~mm}^{2}$ (n.v.: $0.7-1.2 \mathrm{~mm}^{2}$ ). The histogram of the distribution of myelinated fibre diameters revealed a unimodal curve, peaking at 4.5-5.0 $\mu \mathrm{m}$ (Figure 3). The frequency of fibres with focally irregularly folded myelin was $44 \%$.

The ratio of myelin to axon areas was low, suggesting a general hypomyelination (Figure 4). G-ratio values (axon $\emptyset /$ total fibre $\varnothing$ ) ranged widely: from 0.23 to 0.88 (normal 0.6 0.8 ), indicating a great variability in myelin thickness.

Ultrastructural examination showed that the parts of the myelin sheath with irregular contour and thickness seemed to present excessive outfoldings of the myelin itself toward the Schwann cell cytoplasm, thus not affecting the general form of the axon (Figure 5). However, in some cases this excessive folding was inward, toward the axon (infoldings), and the axon was 


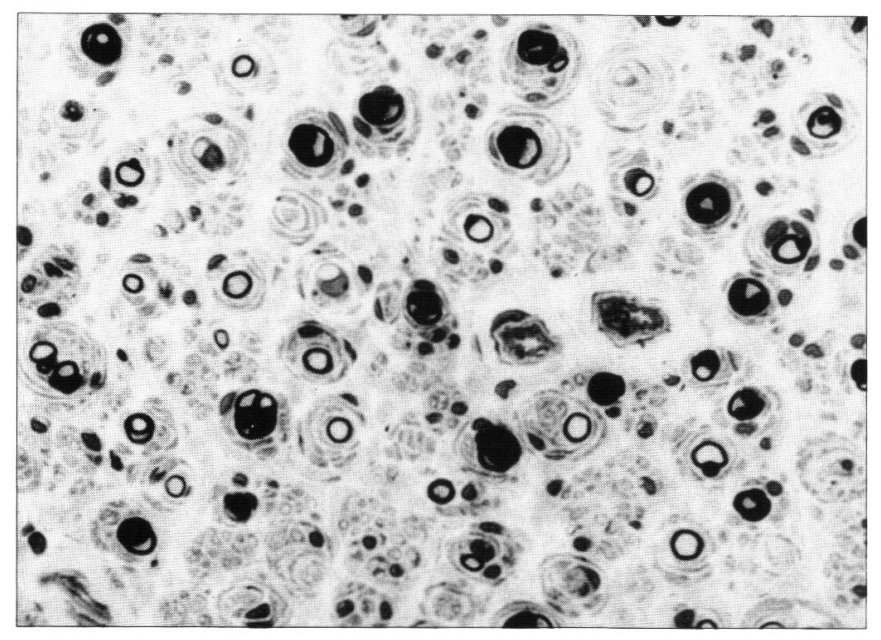

Figure 1: Sural nerve biopsy (patient l). Transverse section showing marked fibre loss, presence of various onion bulbs, aspects of de-and remyelination and many fibres with myelin sheath characterized by highly irregular contour and thickness. Semithin section. Toluidine blue stain. Original magnification x 640 .

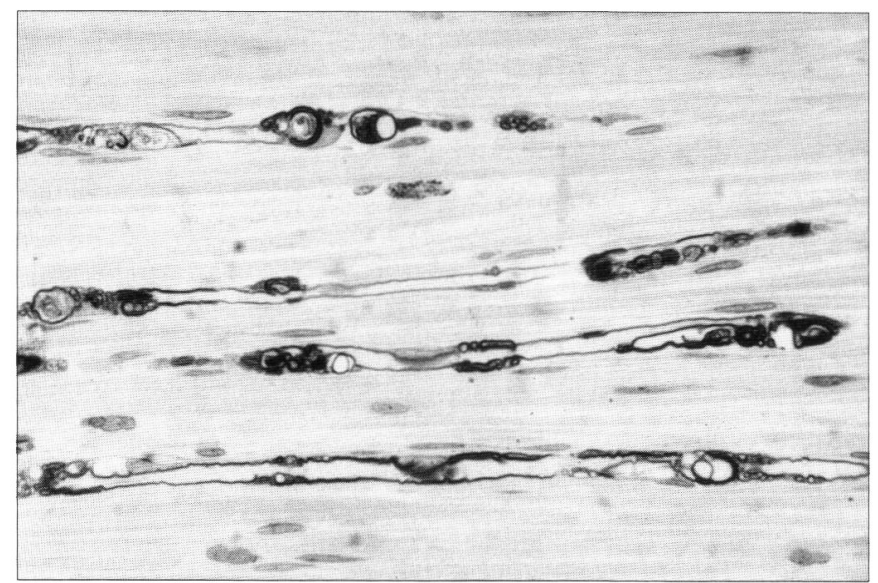

Figure 2: Sural nerve biopsy (patient I). Longitudinal section showing irregular myelin foldings in internodal and paranodal portions of some nerve fibres. Semithin section. Toluidine blue stain. Original magnification $\times 640$.

thus deformed. The general picture of this myelin modification was extremely varied, the myelin often presenting regressive signs in relation to these out-and infoldings. Outside of the regions of excessive foldings, the myelin enclosing the axon was usually disproportionately thin with respect to axon calibre. Some axons were completely demyelinated; many onion bulbs were observed.

\section{Discussion}

Autosomal recessive HMSN with excessive myelin outfolding has peculiar pathological aspects. The general picture is that of a hypertrophic neuropathy, with onion bulbs and de- and remyelination phenomena; however, the diffuse presence of marked myelin changes (out- and infoldings) clearly distinguishes it from HMSN type I and III, although out- and infoldings are not specific in themselves, since they can be found in several disorders, albeit infrequently.

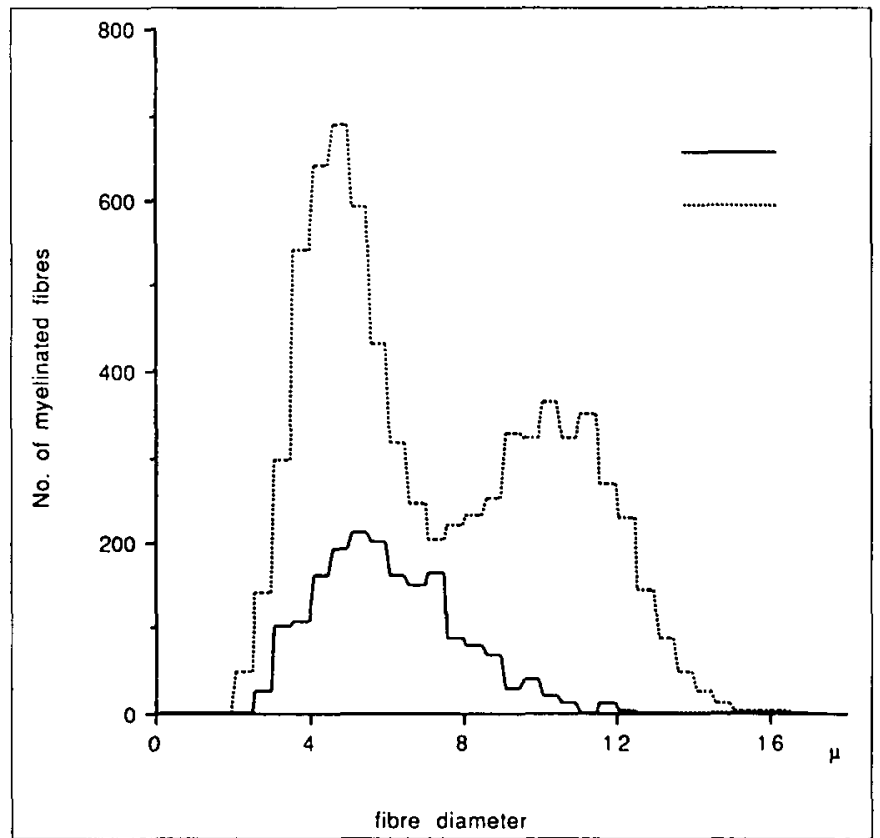

Figure 3: Histogram of distribution of myelinated fibre diameter (patient I). Note the severe reduction in number of myelinated fibres and the unimodal type curve in the nerve of patient I (continuous line) compared to a normal histogram (dotted line).

These two cases are further examples of this disorder. The most likely transmission modality in these cases is autosomal recessive, given the consanguinity of the parents (first cousins), despite the fact that we could not examine the father, deceased. In keeping with the cases of Ohnishi et al. ${ }^{14}$ is the presence in ours of severe distal amyotrophy in the upper limbs and marked reduction in muscle strength. Our patients' electrophysiological and pathological pictures were virtually identical to those of Ohnishi et al. ${ }^{14}$ Besides the ultrastructural images revealing the peculiar findings of excessive myelin outfolding, it is also important to note the results of the morphometric study (G-ratio, myelin / axon areas ratio) showing hypomyelination with foci of hypermyelination linked with myelin outfoldings.

Focal myelin thickenings with or without hypomyelination are a feature of the congenital demyelinating motor and sensory neuropathy. ${ }^{9-13}$ Unlike the cases of Ohnishi et al. and ours, in this sporadic/autosomal recessive affection the onset is before the age of two years. Morphologically, focal myelin thickenings show a more regular profile in this form, with the exception of the cases described by Vallat et al.," as compared with the irregular myelin outfoldings of the form of Ohnishi et al. ${ }^{14}$ Whether these two neuropathies are distinct or represent two forms of a single disorder distinguishable only by onset and course is, therefore, a matter for discussion.

Focal abnormalities of the myelin sheath are also found in tomaculous neuropathy. ${ }^{19}$ However this condition has autosomal dominant transmission and usually manifests before age 20 with pressure palsy of a peripheral nerve; a high number of tomacula are present as myelin thickenings with a regular external surface, unlike thickenings due to outfoldings. Furthermore, ultrastructural studies show that these tomacula consist of an excessive number of normal myelin lamellae, or foldings and 


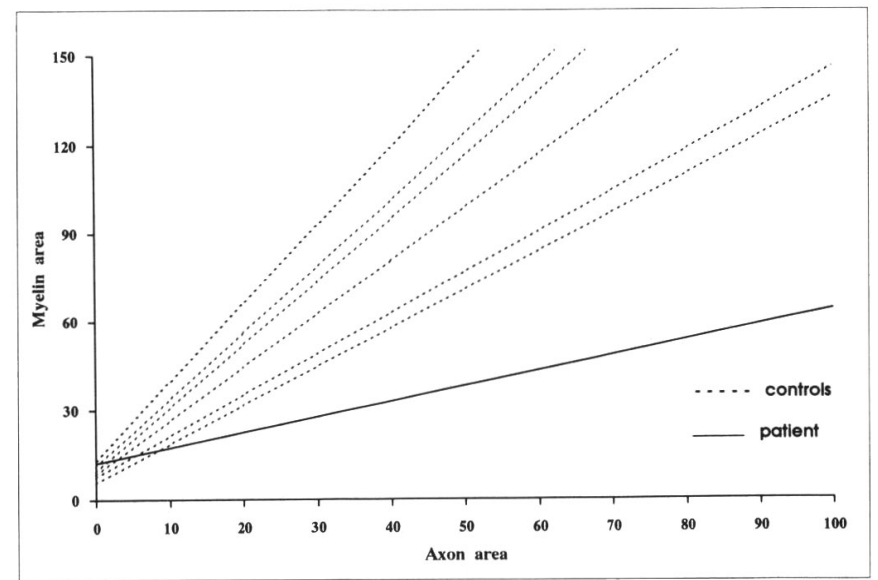

Figure 4: Ratio of myelin area: axon area in normal control subjects and in our patient (patient 1). There is a basic reduction in myelin thickness.

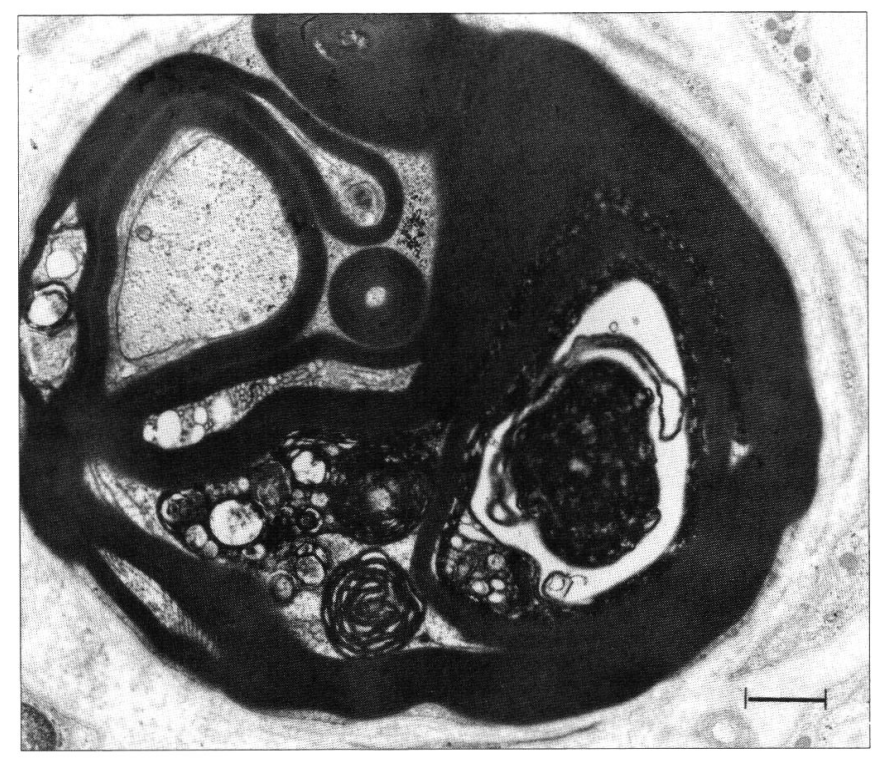

Figure 5: Electronmicrograph of sural nerve biopsy (patient l) showing a nerve fibre with irregular myelin outfoldings. Uranyl acetate and lead citrate stain. Original magnification $\times 12,000$. Bar $=1 \mu \mathrm{m}$.

reversals of redundant myelin loops surrounding the outside of the previous myelin sheath. On the contrary, in the form described by Ohnishi et al. ${ }^{14}$ the myelin sheath irregularly outfolds toward the Schwann cell cytoplasm, and does not surround the axon.

Finally, the globular neuropathy described in two patients by Dayan et al.,20 transmitted as an autosomal dominant trait, certainly in the first and probably in the second case, is not well defined from a pathological viewpoint and may be classified on the basis of various criteria as HMSN type I. ${ }^{13}$

The pathogenesis of excessive myelin outfolding may be related to a primary Schwann cell or myelin sheath defect, ${ }^{21}$ or be secondary to an axon abnormality, 22.23 or it could be traced to a congenital defect affecting interactions between the axon and its myelin during myelin formation. ${ }^{11.13}$

The clinical data, mode of transmission, and especially the morphological findings of HMSN with excessive myelin outfolding suggest a disorder different from the better known forms of HMSN. Only molecular genetic analysis will establish whether it is a variant or a unique form of HMSN.

\section{REFERENCES}

1. Guzzetta F, Ferriere G, Lyon G. Congenital hypomyelination polyneuropathy: pathological findings compared with polyneuropathies starting in later life. Brain 1982; 105:395-416.

2. Dyck PJ, Change P, Lebo R, Carney JA. Hereditary motor and sensory neuropathies. In: Dyck PJ, Thomas PK, Griffin JW, Low PA, Poduslo JF, eds. Peripheral Neuropathy, third ed. Philadelphia: W.B. Saunders, 1993: 1094-1136.

3. Raeymaekers P, Timmerman V, Nelis E, et al. Duplication in chromosome 17 pl1.2 in Charcot-Marie-Tooth neuropathy type la (CMT 1a). Neuromusc Disord 1991; 1: 93-97.

4. Lupski JR, De Oca-Luna RM, Slaugenhaupt S, et al. DNA duplication associated with Charcot-Marie-Tooth disease type la. Cell 1991; 66: 219-232.

5. Bird TD, Ott J, Giblett ER. Linkage of Charcot-Marie-Tooth neuropathy to the Duffy locus on chromosome 1. Am J Hum Genet 1992; 34: 388-442.

6. Lebo RV, Lynch E, Bird TD, et al. Chromosome I Charcot-MarieTooth syndrome (HMSN Ib) locus in Fcy RII gene region. Hum Genet 1992; 88: 1 .

7. Gal A, Mucke J, Theile H, et al. X-linked dominant Charcot-MarieTooth: suggestion of linkage with a cloned DNA sequence from the proximal Xq. Hum Genet 1985; 70: 38-43.

8. Fischbeck KH, ar-Rushdi N, Rozear M, et al. X-linked neuropathy gene localization with DNA probes. Am J Hum Genet 1985; 37: A153.

9. Nordborg C, Conradi N, Sourander P, Hagberg B, Westerberg B. Hereditary motor and sensory neuropathy of demyelinating and remyelinating type in children. Ultrastructural and morphometric studies on sural nerve biopsy specimens from ten sporadic cases. Acta Neuropathol 1984; 65: 1-9.

10. Lütschg J, Vassella F, Boltshauser E, Dias K, Meier C. Heterogeneity of congenital motor and sensory neuropathies. Neuropediatrics 1985; 16: 33-38.

11. Vallat JM, Gil R, Leboutet MJ, Hugon J, Moulies D. Congenital hypo- and hypermyelination neuropathy. Acta Neuropathol 1987; 74: 197-201.

12. Vital A, Vital C, Riviere JP, Brechenmacher C, Marot J. Variability of morphological features in early infantile polyneuropathy with defective myelination. Acta Neuropathologica 1987; 73: 295300.

13. Gabreëls-Festen AAWM, Joosten EMG, Gabreëls FJM, et al. Congenital demyelinating motor and sensory neuropathy with focally folded myelin sheaths. Brain 1990; 113: 1629-1643.

14. Ohnishi A, Murai Y, Ikeda M, et al. Autosomal recessive motor and sensory neuropathy with excessive myelin outfolding. Muscle \& Nerve 1989; 12: 568-575.

15. Schenone A, Uccelli A, Bianchini D, et al. Hereditary motor and sensory neuropathy with excessive myelin outfolding. Clin Neuropathol 1991; 3: 164.

16. Buchthal F, Rosenfalck A. Evoked action potentials and conduction velocity in human sensory nerves. Brain Res 1966; 3: 1-122.

17. Behse F, Buchthal F. Normal sensory conduction in nerves of the leg in man. J Neurol Neurosurg Psychiatry 1971; 94: 241-262.

18. Rosenfalck A, Rosenfalck P. Electromyography, sensory and motor conduction. Findings in normal subjects. Copenhagen: Rigshospitalet $1975 ; 1-49$.

19. Madrid R, Bradley WG. The pathology of neuropathies with focal thickening of the myelin sheath (tomaculous neuropathy). Studies on the formation of the abnormal myelin sheath. J Neurol Sci 1975; 25: 415-448.

20. Dayan AD, Graveson GS, Robinson PK, Woodhouse MA. Globular neuropathy. A disorder of axons and Schwann cells. J Neurol Neurosurg Psychiatry 1968; 31: 552-560. 
21. Dyck PJ, Lambert EH, Sanders K, O'Brien PC. Severe hypomyelination and marked abnormality of conduction in Dejerine-Sottas hypertrophic neuropathy: myelin thickness and compound action potential of sural nerve in vitro. Mayo Clin Proc 1971; 46: 432436.

22. Nukada H, Dyck PJ, Karnes JL. Thin axons relative to myelin spiral length in hereditary motor and sensory neuropathy type $\mathrm{I}$. Ann Neurol 1983; 14: 648-655.
23. Dyck PJ, Nukada H, Lais AC, Kames JL, Permanent axotomy: a model of chronic neuronal and axonal atrophy, myelin remodeling and axonal degeneration. In: Dyck PJ, Thomas PK, Lambert EH, Bunge R, eds. Peripheral Neuropathy, second ed. Philadelphia: W.B. Saunders, 1984: 666-690. 